\title{
Non-English Major Students' Perception of Factors Influencing English Proficiency in China
}

\author{
Wu Yuntao ${ }^{1}$ \\ ${ }^{1}$ Faculty of Education, SEGI University, Kota Damansara, Malaysia \\ Correspondence: Wu Yuntao, No 9, Jalan Teknologi Taman Sains Selangor, Kota Damansara PJU 5, Petaling \\ Jaya, Selangor, Malaysia.
}

Received: January 15, 2019

Accepted: March 18, 2019 Online Published: March 21, 2019

doi: $10.5539 /$ elt.v12n4p157

URL: https://doi.org/10.5539/elt.v12n4p157

\begin{abstract}
This study aims at investigating Non-English major students' perception of factors that influencing English proficiency in China. The research was conducted by using a non-experimental quantitative research design by a questionnaire survey. A total 300 Non-English Major students from second year from different duration of learning English in Henan Polytechnic University was collected to complete this survey. The research findings revealed the learning strategies of Non-English major students in Henan Polytechnic University has most significantly affect on English proficiency among four potential factors. The hypothesis testing results indicated that the perception of students who began learning English from primary school were statistically significantly higher than those who began learning English from middle school with respect to factors influencing English proficiency. The findings recommended that the government should provide more supports to English language learning in primary school, the English teacher should pay attention to male students' English learning and help students improve their learning strategy in English learning.
\end{abstract}

Keywords: English proficiency, Non-English major, motivation, learning strategies, beliefs about English learning and distance between students' first language and English language

\section{Introduction}

$\mathrm{Hu}(2005)$ observes that "since China embarked on its modernization drive, policy statements and mass media have constructed a discourse that has linked national English proficiency and socioeconomic development. On a national dimension, English, as an international language in foreign language, is playing a crucial role in national modernization and development. On an individual dimension, English is used for career advancement and improve personal quality. Students in Chinese school begin learning English either from primary school or middle school. From the year of 2003, English officially entered primary schools as a compulsory teaching subject for the third-year pupils in China, and key schools were encouraged to teach English from the first-year (MOE, 2011). There is flexibility for school principals and local education departments for the 'earlier' introduction of English. The current situation is that students who learn English begin from middle school in some place, but some other students begin to learn English from primary school in developed cities or big cities.

Meanwhile, most Chinese students who have spent over ten years on learning English from primary school to college still cannot speak or listen or read or even write the language, let alone fluently (Luo, 2013). Students coming into Chinese universities have not attained a satisfactory proficiency level in the English language. These problems related to English language mastery of students entering universities have been investigated by many researchers in China (Sun, 2014; Yun, 2014; Wei, 2016). Among the areas investigated include motivation, language aptitude, anxiety, self-esteem, individual character, learning preference and intelligence (Sun, 2014). Perhaps there is a combination of factors that, influence English proficiency of Non-English major students instead of single factors such as motivation or learning strategy.

The English language departments at universities and colleges and instructors have been trying to help students to improve their English language skills, but with limited or little success. A possible reason could be that the instructors may lack knowledge and insight on how to improve English proficiency of Non-English majors in Chinese instructors of higher learning. 


\section{Literature Review}

\subsection{Motivation}

The motivation usually explains the reasons for human's desires, needs and actions. Motivation can also be defined as one's direction to behavior or what causes a person to want to repeat a behavior and vice versa (Elliot \& Covington, 2001). In traditional psychology, it is believed that motivation is the reflection of the internal driving force such as instincts, willingness and mental force, or caused by stimulus and reinforcement, and is generally understood as the static state of mind.

Deci and Ryan's (1985) self-determination theory focuses on two motivation orientations: the first is the intrinsic interest in learning activities; the second is the reward outside learning activities. They divide learning motivation into three categories, namely, no motivation, extrinsic motivation and intrinsic motivation. Intrinsic motivation refers to that learners have the desire to learn a foreign language because of their curiosity and interest. Extrinsic motivation refers to that the foreign language learners learn a foreign language in order to win praise or exempt from punishment. They believe that these three kinds of motivation are in the same continuum, and the degree of self-determination is from low to high. No motivation has the lowest degree of self-determination on this continuum (Hua, 2009).

\subsection{Learning Strategies}

Language learning strategies are generally defined as the EFL learner's consciously chosen tools for active, self-regulated improvement of language learning (Shinozuka, Shibata, \& Mizusawa, 2017).There are a number of ways to categorize types of learning strategies (Gan, Humphreys, \& Hamp-Lyon, 2004; O’Malley, Chamot, Stewner-Manzanares, Kupper, \& Russo, 1985). O'Malley and Chamot (1985) divide language learning strategies into three main kinds. The first type is meta-cognitive strategy, which involves selective attention, planning, self-assessment and self-monitoring. The second kind is cognitive strategy concerning the steps or operations in the process of directly analyze the learning materials. The last language learning strategy is social and affective strategies, which concern interaction with others and ideational control over emotion. Oxford (1990) divided the strategies into two major classes: direct and indirect. The direct strategies are composed of cognitive, memory and compensation strategies. The indirect strategies involve meta-cognitive, social and affective strategies.

\subsection{Beliefs About English Learning}

Barcelos (2003) claimed that all the definitions which he concluded have stressed on learners' beliefs upon language learning referred to the nature of language. Definitions given by other researchers put emphasis on the social and culture nature of language learning beliefs. They believe that these beliefs did not only have a cognitive dimension, but also a social dimensions, because they were born out of our communications with others and the environments we are in. Certainly, understanding students' beliefs meant understanding their world and their identity

According to Lu (2013) college students' learning beliefs is a multidimensional structure, which is based on the beginning of knowledge, including essence beliefs and motivated beliefs of the subjective beliefs in the whole system. Wen (2001) pointed out that a lot of elements were included in the methods of learning English. Learning beliefs and learning strategies were contained in these factors. Learners form their specific beliefs by their individual learning or through learning from others. Beliefs maintain a state of stability and affect language learning profoundly and subtly.

\subsection{Distance Between Students' First Language and English}

English and Chinese belongs to two completely different language families and have many significant differences in several aspects, which make learning English a huge challenge for Chinese native speakers (Shoebottom, 2011). The differences between English and Chinese in phonetic communities and labial characteristics make English sounds difficult to pronounce. Besides, Chinese speakers' English pronunciations are commonly attached with heavy regional Chinese accents due to hundreds of dialects in China, including Taiwanese, Wu and Cantonese, most of which differ dramatically from each other (Wang, 2017).

Many researches have shown that language acquisition occurs more easily when the linguistic distance between the first language and the target language is less (Chiswick \& Miller, 2005; White, 2003). Linguistic distance refers to the differences in the meaning, the structure, and the use of words between the first language and the target language. For instance, English is linguistically closer to Western European languages, such as French and German, than it is to East Asian languages, such as Korean and Japanese. It would be expected that Western European students have less learning burden than students from East Asia. 


\section{Methodology}

The research was conducted by using a non-experimental quantitative research design that used a questionnaire survey. The aim of this survey is to identify factors that influence English language proficiency of Non-English Major students in Henan Polytechnic University. It also aims to establish the extent to which these factors (Beliefs about English learning, learning strategies, motivation, distance between students' first language and English and gender) influence students' English language proficiency.

\subsection{Participants}

These 300 respondents were selected from 3 separated faculties from a total of 19 faculties in Henan Polytechnic University. The convenient sample of 300 students was selected from 7970 sophomore students in Henan Polytechnic University, who were registered for 2017/2018 academic year. Out of the 300 students who took part in this study, 163 were male students, accounting for 54.3 percent. The rest of 137 students were female students.

\subsection{Instruments}

A 60-item questionnaire developed by (Chou, 2007) was adapted for this study and was used to collect quantitative data. Further, the influence of the number of years of learning English of students on the perception of factors influence English language proficiency is explored in this study.

\section{Findings and Discussion}

The researcher analyzed the data by SPSS using descriptive analysis, Pearson Correlation, T-test and multiple regressions. The English proficiency of Non-English Major students is measured as the results of CET-4 (College English Test-4) in China.

\subsection{Descriptive Statistical Analysis}

The data shows show that that the CET-4 results of female (137) and male (163) students. There were 27 female and 14 male students in the High group; 53 female and 67 male students in the Moderate group and 57 female students and 82 male students in the Low group ( Table 1).

Table 1. Distribution of CET-4 Results by Gender

\begin{tabular}{lllll}
\hline Gender & N & High & Moderate & Low \\
\hline Female & 137 & 27 & 53 & 57 \\
Male & 163 & 14 & 67 & 82 \\
Total & 300 & 41 & 120 & 139 \\
\hline
\end{tabular}

Note. $\mathrm{N}=$ Number of respondents.

According to participant's background, students were classified into two groups according to the number of years they began learning English in school. Students who began learning English from Primary school had more than 6 years of English language learning experience. Students who began learning English from Middle school had 6 years or less of English language learning.

Table 2 shows that 174 students $(58.0 \%)$ commenced learning English from Primary school and 126 students (42.0\%) commenced learning English from Middle school.

Table 2. Distribution of respondents' learning English from school

\begin{tabular}{lll}
\hline School & Frequency & Percent \\
\hline Primary School ( $>6$ years) & 174 & 58.0 \\
Middle School ( $\leq 6$ years) & 126 & 42.0 \\
Total & 300 & 100.0 \\
\hline
\end{tabular}

Respondents were asked to check all reasons for learning English. Entries in the Table 3 show that 5 reasons were given by respondents for learning English. The reasons are as followed: (1) There were interested in the language, (2) They were required to take the course, (3) They needed English for future career, (4) They need 
English for college acceptance, and (5) The English is not difficult to learn. Most respondents believed that they learned English because it is not difficult to learn (38.6.0\%), followed by the reason that they need English for future career $(32.9 \%)$.

About $15 \%$ of the respondents believe that they were interested in English. About $9 \%$ of respondents said they English for college acceptance and 5\% said that they need English course to graduate.

Table 3. Frequency and percentages of reasons for learning English

\begin{tabular}{lll}
\hline Statements & $\mathrm{N}$ & Percent \\
\hline I believe English is not difficult to learn. & 243 & $38.6 \%$ \\
I need it for my future career. & 207 & $32.9 \%$ \\
I am interested in this language. & 94 & $14.9 \%$ \\
I need it for acceptance to university/college in the university. & 55 & $8.7 \%$ \\
I am required to take this course in order to graduate. & 31 & $4.9 \%$ \\
Total & 300 & $100 \%$ \\
\hline
\end{tabular}

Based on the findings students rated motivation to learn English as the highest in perceived importance $(\mathrm{M}=3.83$, $\mathrm{SD}=0.737)$. The mean and standard deviation of the Beliefs about language learning scale was $(\mathrm{M}=3.79$, $\mathrm{SD}=0.688)$. The mean and standard deviation of Learning Strategies scale was $(\mathrm{M}=3.66, \mathrm{SD}=0.784)$. The mean and standard deviation of Distance between first language and English was $(\mathrm{M}=3.29, \mathrm{SD}=0.773)$ in Table 4.

Table 4. Distribution of mean, standard deviation and number of items

\begin{tabular}{llll}
\hline Factors & N & Mean & Std.Deviation \\
\hline Motivation & 5 & 3.83 & 0.74 \\
Beliefs about English learning & 5 & 3.78 & 0.74 \\
Learning Strategies & 10 & 3.66 & 0.78 \\
Distance between students' first language and English & 4 & 3.29 & 0.77 \\
\hline
\end{tabular}

Note. $\mathrm{N}=$ Number of Items.

Language learning motivation refers to the desire of students to learn a foreign language and the driving force of learners, it is the catalyst in many individual factors for language learning, and is also one of the most important factors to successful language learning. The influence of motivation in language achievement is clear and proves that motivation is a determinant factor in achieving proficiency in a second or a foreign language. Zhang (2015) indicates that language learning motivation is one of vital factors which strongly correlated with the success in second language acquisition. Motivation can sustain students' desire to accomplish learning tasks and generate new desire to start further learning. When learners are motivated, they internalize the need for learning and develop a self urge towards learning. (Makewa, Role, \& Tuguta, 2013). Also, Yamashiro and Mclaughlin (2001) replicated the study in Japanese EFL contexts and concluded similarly that motivation had significant influence on language proficiency. The tremendous influence that motivation has in language achievement is one of the reasons why researchers pay so much attention to develop motivation tasks and strategies that can help learners feel more motivated and enthusiastic to learn a language (Fernández, 2013).

The second highest mean score and standard deviation was observed for the Beliefs about Learning English scale $(\mathrm{M}=3.78, \mathrm{SD}=0.742)$. The Beliefs about language learning refers to opinions or views held by people about language learning. The beliefs considerably impact on both the progress and success of any learning activity, as well as exerting a direct influence on English achievement. It has been found that the students' English learning beliefs is generally a strong influencing factor of English achievements (Ren \& Bai, 2016).

The third highest mean score and standard deviation was observed for Learning Strategies scale was $(M=3.66$, $\mathrm{SD}=0.784$ ). Language learning strategies refer to the processes and action that are consciously utilized by language learners to help them to learn a language more effectively. Oxford (2001) has found that learning 
strategies are of great importance, especially for language learners because they enhance active, autonomous involvement in language learning process and this is important for developing communicative competence, which is the ultimate goal of language classes. Also, Oxford explicitly suggests that language learning strategies is among the key factors in determining the quality of student learning in second (L2) and foreign language. It is assumed that the students who have employed certain strategies would report better language achievement (Setiyadi, Sukirlan, \& Mahpul, 2016). Fewell (2010) indicates that language learning strategies are thought to be an "effective and workable" (p. 159) factor in language learning process among other important factors affecting L2 acquisition because they are controllable and it is possible to manipulate and manage strategies in order to improve language learning.

The fourth highest mean score and standard deviation was observed for Distance between first language and English was $(\mathrm{M}=3.29, \mathrm{SD}=0.773)$. Language distance is the difference in the form, the meaning, the structure, and the use of words between first language and the second language. Crystal (1987, p. 371) in The Cambridge Encyclopedia of Language writes regarding linguistic distance: "The structural closeness of languages to each other has often been thought to be an important factor in foreign language learning. If the second language is structurally similar to the original language (first language), it is claimed that language learning should be easier than in cases where the second language is very different form first language. Moreover, it shows, when other determinants of English language proficiency are the same, the closeness of the linguistic distance, the greater is the respondent's English language proficiency (Chiswick \& Miller, 2005).

In conclusion, this analysis shows that language learning motivation is most important factor that contributes to English proficiency of sophomore Non-English Major students in Henan Polytechnic University.

Table 5. Distribution of means, standard deviation, t-value and p-value of the students who began learning english from primary school and those who began learning english from middle school with respect to the four factors

\begin{tabular}{llllll}
\hline Factors & Students(N=300) & Mean & SD & t & $\mathrm{p}$ \\
\hline Learning Strategies & Primary school(N=174) & 3.83 & 7.676 & 4.34 & $.000^{* * *}$ \\
& Middle school (N=126) & 3.44 & 7.554 & & \\
Distance between students' first & Primary school(N=174) & 3.38 & 3.118 & 2.22 & $.027^{*}$ \\
language and English & Middle school (N=126) & 3.18 & 3.013 & & \\
Motivation & Primary school(N=174) & 3.92 & 3.583 & 2.46 & $.014^{*}$ \\
& Middle school(N=126) & 3.71 & 3.754 & & \\
Beliefs about learning English & Primary school(N=174) & 3.84 & 3.636 & 1.47 & $.140^{*}$ \\
& Middle school(N=126) & 3.71 & 3.771 & & \\
\hline
\end{tabular}

Note. ${ }^{*} \mathrm{p}<0.05,{ }^{* *} \mathrm{p}<0.01,{ }^{* * *} \mathrm{p}<0.001$.

The results in Table 5 shows that there are statistically significant differences in the perception of factors influencing the learning of English between students who began learning English from Primary school and those who began learning English from Middle school.

In the Learning Strategies scale, the mean score of students who began learning English from Primary school $(\mathrm{M}=3.83, \mathrm{SD}=7.676)$ was statistically significantly higher than those who began learning English from Middle school $(\mathrm{M}=3.44, \mathrm{SD}=7.554 ; \mathrm{t}(298)=4.34 ; \mathrm{p}<0.001$, two-tailed). In the Distance between students' first language and English scale, the mean score of students who began learning English from Primary school $(\mathrm{M}=3.38$, $\mathrm{SD}=3.118$ ) was statistically significantly higher than those who began learning English from Middle school $(\mathrm{M}=3.18, \mathrm{SD}=3.013 ; \mathrm{t}(298)=2.22 ; \mathrm{p}<0.05$, two-tailed $)$. In the Motivation scale, the mean score of students who began learning English from Primary school $(\mathrm{M}=3.92, \mathrm{SD}=3.583)$ was statistically significant higher than those who began learning English from Middle school $(\mathrm{M}=3.71, \mathrm{SD}=3.753 ; \mathrm{t}(298)=2.46 ; \mathrm{p}<0.05$,two-tailed). However, there are no statistically significant differences between students who began learning English from Primary school $(\mathrm{M}=3.84, \mathrm{SD}=3.636)$ and those who began learning English from Middle school $(\mathrm{M}=3.71$, $\mathrm{SD}=3.771 ; \mathrm{t}(298)=1.47 ; \mathrm{p}=0.14>0.05$,two-tailed) in Beliefs about Learning English scale.

The results of the study shows that the perception of students who began learning English from primary school 
with respect to four factors, Learning Strategies, Distance between students' first Language and English and Motivation were statistically significantly higher than those who began learning English from middle school. In the year 2001, English was introduced in primary schools as a compulsory teaching subject for the third-year pupils in China, and key schools were encouraged to teach English from the first-year of schooling. In different provinces, the government made a policy to bring English course in middle school or primary school according to their financial supports. Most of the local educational departments do not offer the English course for the students in primary school. This situation leads to some students spent 6 years in learning English if they began learning English form middle school. Some students spend more than 6 years in learning English they began learning English form primary school. Some cities like Beijing, Shanghai and Guangzhou, their students even began learning English from first-year of schooling. Consequently, due to the low investment from the local government, many schools are not equipped with the facilities necessary for the English teaching and learning. The facilities play a very important role in the English teaching and learning, such as the multimedia computer, the Internet connections, and the laboratory (Bing, 2017). Before entering College and universities, there are some differences in students' English proficiency due to birthplace and policy.

Many years has passed since English entered primary schools as a teaching subject. Pupils who took English ten years ago have entered colleges or universities, and the impact of the advent of primary English has begun to express itself in college English education. The differences of English proficiency between students who learn English from primary school and those who learn English from middle school brings some potential challenge for English teachers in English education. The government has been trying many English education revolution to cope with these matters. China started to implement a new standard curriculum for English in primary schools in 2003 (Ping, 2013). The English teachers in primary school are organized to further English study in universities through some programs that are initiated by the government.

The result of this study shows that the earlier students learn English language, the higher it impacts on English proficiency of students.

\subsection{Inferential Statistics Analysis}

Table 6. Multiple regression coefficientsa

\begin{tabular}{|c|c|c|c|c|c|c|c|c|c|}
\hline \multirow[t]{3}{*}{ Model } & \multirow{2}{*}{\multicolumn{2}{|c|}{$\begin{array}{l}\text { Unstandardized } \\
\text { Coefficients }\end{array}$}} & \multirow{3}{*}{$\begin{array}{l}\text { Stand } \\
\text { Coeffi } \\
\text { Beta }\end{array}$} & \multirow[t]{3}{*}{$\mathrm{t}$} & \multirow[t]{3}{*}{ Sig. } & $95.0 \%$ & \multicolumn{3}{|c|}{ Confidence Collinearity } \\
\hline & & & & & & \multicolumn{2}{|c|}{ Interval for B } & \multirow{2}{*}{\multicolumn{2}{|c|}{$\begin{array}{l}\text { Statistics } \\
\text { Tolerance VIF }\end{array}$}} \\
\hline & B & Std. Error & & & & Lower & Upper & & \\
\hline (Constant) & -164.051 & 32.933 & & -4.981 & .000 & -228.864 & -99.238 & & \\
\hline Strategy & 5.588 & .802 & .339 & 6.966 & .000 & 4.009 & 7.167 & .675 & 1.481 \\
\hline Motivation & 9.432 & 2.033 & .268 & 4.639 & .000 & 5.430 & 13.433 & .477 & 2.098 \\
\hline Belief & 5.124 & 1.881 & .146 & 2.724 & .007 & 1.422 & 8.825 & .553 & 1.809 \\
\hline Distance & 4.318 & 1.916 & .138 & 2.254 & .025 & .547 & 8.089 & .427 & 2.341 \\
\hline
\end{tabular}

In this research, a step-wise multiple regression analysis was carried out and a regression model comprising 4 predictor variables was found to make unique contribution to the dependent variable English proficiency. The data shows that the final model-4 comprising Motivation, learning Strategies, Belief, Distance made unique contribution to the dependent variables English proficiency.

In Table 6, the Multiple Regression model with all four predictors produced ( $\mathrm{R}$ square $=0.529, \mathrm{~F}(4,295)=82.99$, $\mathrm{p}<0.000$ ). The research shows that Learning Strategies scale (beta $=0.34, \mathrm{t}=6.966 . \mathrm{p}<0.05$ ) had significant regression weight indicating that students perceived that Learning Strategies made significant impact on Non-English major students' English proficiency. After that, the beta weight for Motivation scale was 0.27(.t=4.639. $\mathrm{p}<0.05)$. The beta weight for Belief about Learning English scale was 0.15(.t=2.724. $\mathrm{p}<0.05)$. The beta weight for the Distance between students' first language and English was $0.14(t=2.254$. $p<0.05)$.

Different findings were reported by Magogwe and Oliver's (2007) in a study which involved primary, secondary and tertiary level students, indicated that in general there was no significant interaction between proficiency and learning strategies though there was an indication of interaction between them at the primary level. In addition, Oxford and Nyikos (1989) fond that motivation is the best predictor of language learners' achievements of 
college students and it plays an influential role strategy use. Schumer (1994) studies showed that the learning belief has a strong effect on learner's information processing system and learning achievements. According to Adigüzel and Orhan (2017), Distance between students' first language and English is important for language-learning achievement. Because, the learning process for language learners includes too many novelties, unknown rules, different writing systems, and unconventional instructional approaches, students, who have a clear cognition to learn English, do not lose their focuses and achieve great goals in English learning.

The result of this study shows that Learning Strategies among four factors is most important predictor in English language proficiency in sophomore Non-English Major students in Henan Polytechnic University.

\section{Conclusion}

The study revealed that the language learning motivation is the most important factor contributing English language proficiency. With respect to the motivational factors, the Henan Polytechnic University authorities and English teachers could explore different way of motivating Non-English Major students to learn English. The authority and teachers could explore ways to encourage these students to revise their English lessons, and how to improve their writing skills. This is necessary to tackle some of the problems found among students in this study, particularly on how to motivate them to improve their English proficiency. This could be achieved by giving them more exercises and assignments on writing, speaking, listening and reading in English. English teachers should encourage students to manage their own learning by guiding students to choose what kind of learning task and to make the individual learning plan. They give students the direction of the task and encourage students to actively participate in various activities. When students are confused in learning, teachers give students some advice about what to do next, and the decisions are made by students themselves.

What may also be profitable for the teachers to do is to further exploit the students' intrinsic motivation to learn English. This can be done by the contextualization of exercises and other classroom activities so that English is practiced in situation that realistically reflect the use of it in the world outside. In this way, the teacher could stimulate and sustain the students' interest in learning English and so increase their intrinsic motivation.

In addition, learning strategies was found to significantly affect English proficiency. There is therefore a need for Henan polytechnic University authorities and teachers to explore new and innovative learning strategies for students to learn English. It is also quite necessary for learners to master some learning strategies to improve their learning efficient and perfect learning result. Initially, Non-English Major students must have a thorough understand of their learning state: what are the strategies they often use and how their learning strategies affect learning. Then the Non-English Major students should follow teachers' strategy training or instruction and change previous learning strategies. English teachers should introduce various learning strategies to help Non-English Major students improve their writing, speaking, listening and reading skill. Non-English Major students need actively participate in English competition in Henan Polytechnic University. In this process Non-English Major students should develop the awareness to use those new strategies as possible as they can. Only by practice can they master the strategies. English Teachers also should examine why the learning strategies are necessary in many of these Non-English Major students in Henan Polytechnic University. They should also try to establish the other learning strategies not discussed in this study which may be employed by these Non-English Major students. This is important since it is felt that more will possibly be achieved by guiding and encourage Non-English Major students to change their learning strategies, and to further develop those that are already being used by them.

Also, Lesson hours should also be set aside weekly or fortnightly for activities with the specific purpose of giving students the opportunity to speak, listen to or read English as it is used in authentic contexts. Materials that can be used during such activities include films, taped talks, stories, songs, newspapers, comics, popular magazines about football, pop stars or women's magazines. However, it should be pointed out that the emphasis of all the activities during these hours would be more for enjoyment rather for assessment or testing purposes.

With regard to the duration of learning English language, the results of this study showed that Non-English major students felt that learning English from Primary schools did have a significant effect on their English language proficiency. This being the case, students should begin learning English language early. It is thus the responsibility of the government and Ministry of Education to provide economic supports and enact policies to develop the primary English learning. More efforts should be made to improve the primary English learning environment and more primary English training school should be built up.

According to a previous study (Yahaya, Lean, Bon, \& Ismail, 2011), the factor influences English proficiency most is student's attitude. But in this study it was found that Motivation to learn English is a major contributor to the English proficiency of Non-English major students. The Distance between students' first Language and 
English does not have the significant relationship with English proficiency, there is however moderately strong relationships between three factors, namely Motivation, Belief about English learning and English Learning Cognition and English proficiency respectively.

Finally, many studies about factors influencing students' English proficiency have investigated for many years (Sun, 2014; Yun, 2014). It is recommended that future studies explore the factors like language aptitude, anxiety, self-esteem, self-efficacy and attitude and these together are related to students' English proficiency.

\section{References}

Adigüzel, A., \& Orhan, A. (2017). The Relation between English Learning Students' Levels of Self-Regulation and Metacognitive Skills and Their English Academic Achievements. Journal of Education and Practice, $8(9), 115-125$.

Barcelos, A. M. F. (2003). Researching beliefs about SLA: A critical review. In Beliefs about SLA (pp. 7-33). Springer, Dordrecht. https://doi.org/10.1007/978-1-4020-4751-0_1

Bing, W. (2017). The College English Teaching Reform Based on MOOC. English Language Teaching, 10(2), 19-22. https://doi.org/10.5539/elt.v10n2p19

Chiswick, B. R., \& Miller, P. W. (2005). Linguistic distance: A quantitative measure of the distance between English and other languages. Journal of Multilingual and Multicultural Development, 26(1), 1-11. https://doi.org/10.1080/14790710508668395

Chou, C. T. (2007). Factors Affecting Language Proficiency of English Language Learners at Language Institutes in the United States. A Dissertation submitted in partial fulfillment of the requirements for the degree of Doctor of Philosophy, Texas Woman's University, Texas, United States.

Crystal, D. (1987). The Cambridge encyclopedia of language (Vol. 2). Cambridge: Cambridge University Press.

Deci, E., \& Ryan, R. M. (1985). Intrinsic motivation and self-determination in human behavior. Springer Science \& Business Media. https://doi.org/10.1007/978-1-4899-2271-7

Elliot, A. J., \& Covington, M. (2001) Approach and avoidance motivation. Educational Psychology Review, 13, 2-19. https://doi.org/10.1023/A:1009057102306

Fernández Orío, S. (2013). Motivation and second language acquisition. Graduate studies' dissertation: Universidad de La Rioja.

Fewell, N. (2010). Language learning strategies and English language proficiency: An investigation of Japanese EFL university students. Tesol Journal, 2(1), 159-174.

Gan, Z., Humphreys, G., \& Hamp-Lyons, L. (2004). Understanding successful and unsuccessful EFL students in Chinese universities. The Modern Language Journal, 88(2), 229-244. https://doi.org/10.1111/j.0026-7902. 2004.00227.x

Hu, G. (2005). Reforms of basic English-language education in China: An overview. International Journal of Educational Reform, 14(2), 140-165. https://doi.org/10.1177/105678790501400202

Hua, W. F. (2009). Motivation and Autonomous. Foreign Language Research, 2(1), 57-62.

Liu, J., \& Dai, Z. (2011). The Impact of the Advent of English in Primary Schools on the Development of College English in China. Higher Education Studies, 1(1), 105-108. https://doi.org/10.5539/hes.v1n1p105

Luo, J. P. (2013). An action research on improvement of reading comprehension of CET4. English Language Teaching, 6(4), 89-96. https://doi.org/10.5539/elt.v6n4p89

Magogwe, J. M., \& Oliver, R. (2007). The relationship between language learning strategies, proficiency, age and self-efficacy beliefss: A study of language learners in Botswana. System, 35(3), 338-352. https://doi.org/10.1016/j.system.2007.01.003

MOE. (2011). Standard English Curriculum in Compulsory Education. Ministry of Education. Beijing.

O’Malley, M. J., Chamot, A., Stewner-Manzanares, G., Kupper, L. \& Russo, R. P. (1985). Learning strategies used by beginning and intermediate ESL students. Language Learning, 35(1), 21-46. https://doi.org/10. 1111/j.1467-1770.1985.tb01013.x

Oxford, R. L., \& Nyikos, M. (1989). Variables affecting choice of language learning strategies by university students. The Modern Language Journal, 73(3), 291-300. https://doi.org/10.1111/j.1540-4781.1989. tb06367.x 
Oxford, R. L. (1990). Language learning strategies. Boston, MA: Heinle \& Heinle publishers.

Oxford, R. L. (2001). Language learning styles and strategies. In M. Celce-Murcia (Ed.), Teaching English as a second or foreign language (pp. 359-366). Boston, MA: Heinle \& Heinle.

Ping, W. (2013). Assessing the impact of 240-credit-hour programme for urban primary school teachers of english in China. English Language Teaching, 6(5), 97-104. https://doi.org/10.5539/elt.v6n5p97

Ren, H., \& Bai, Y. (2016). A Study of the Relationship between Learning Belief and English Achievement of Chinese English Major College Students. Journal of Education and Practice, 7(14), 99-103.

Schommer, M. (1994). Synthesizing epistemological belief research: Tentative understandings and provocative confusions. Educational Psychology Review, 6(4), 293-319. https://doi.org/10.1007/BF02213418

Setiyadi, A. B., Sukirlan, M., \& Mahpul. (2016). How Successful Learners Employ Learning Strategies in an EFL Setting in the Indonesian Context. English Language Teaching, 9(8), 28. https://doi.org/10.5539/elt. v9n8p28

Shinozuka, K., Shibata, S., \& Mizusawa, Y. (2017). Effectiveness of Read-aloud Instruction on Motivation and Learning Strategy among Japanese College EFL Students. English Language Teaching, 10(4), 1. https://doi.org/10.5539/elt.v10n4p1

Shoebottom. (2011). The difference between English and Chinese. Retrieved on 18th November, 2016 from http://esl.fis.edu/grammar/langdiff/chinese.htm

Sun, D. (2014). A Study on the Relationship among English Learning Motivation, Learning Strategies and Language Performance of Non-English Majors.

Wang, K. (2017). Status Quo and Prospective of WeChat in Improving Chinese English Learners' Pronunciation. English Language Teaching, 10(4), 140-149. https://doi.org/10.5539/elt.v10n4p140

Wei, G. (2016). An Empirical study on the correlation between college EFL learner's Beliefs and English achievement. https://doi.org/10.3969/j.issn.2096-2266.2016.09.020

Wen, Q. (2001). (Developmental patterns in motivation, beliefs and strategies of English learners in China). Foreign Language Teaching and Research, 2001(2), 105-110.

White, L. (2003). Second Language Acquisition and Universal Grammar (Cambridge Textbooks in Linguistics). https://doi.org/10.1017/CBO9781107415324.004

Yahaya, A., Yahaya, N., Lean, O. C., Bon, A. T., \& Ismail, S. (2011). Factors contributing to proficiency in English as a second language among Chinese students in Johor Bahru. Elixir Psychology, 41, 5837-5848.

Yamashiro, A. D., \& McLaughlin, J. (2001). Relationships among attitudes, motivation, anxiety, and English language proficiency in Japanese college students. In P. Robinson, M. Sawyer, \& S. Ross (Eds.), Second language acquisition research in Japan: JALT applied materials series (Vol. 4, pp. 19-33).

Yun, M. (2014). A Study on the relationship among English learning Motivation, Learner Autonomy and English Learning Achievements for Non-English Major Undergraduates.

Zhang, J. (2015). Improving English Listening Proficiency: The Application of ARCS Learning-Motivational Model. English Language Teaching, 8(10), 1-6. https://doi.org/10.5539/elt.v8n10p1

\section{Copyrights}

Copyright for this article is retained by the author(s), with first publication rights granted to the journal.

This is an open-access article distributed under the terms and conditions of the Creative Commons Attribution license (http://creativecommons.org/licenses/by/4.0/). 